\title{
PROBLEMATIKA PENERAPAN ASAS RECKLESSNESS DALAM PERSPEKTIF PEMBAHARUAN HUKUM LALU LINTAS DI INDONESIA
}

\author{
Edi As'Adi \\ Program Doktor Ilmu Hukum Universitas Diponegoro \\ E-mail: 454dilaw@gmail.com
}

\begin{abstract}
recklessness is one of the causes of traffic accidents. However, Law No. 22 of 2009 has not implicitly set the application of the principle of recklessness. So in field settings is still referring to the 359 of the Criminal Code, Article 360 of the Criminal Code and Article 492 of the Criminal Code, and even for difficult cases and found no law in the traffic law, judges apply article 338 of the Criminal Code with the principle of dolus eventualis consideration to fill the legal vacuum which are not in traffic law. Based in the future it is necessary reformulation of the principle of Recklessness in traffic law reform based on social justice values of Pancasila.
\end{abstract}

Key words: legal, reckless, renewal, traffic.

\begin{abstract}
Abstrak
Sembrono adalah salah satu faktor penyebab terjadinya kecelakaan lalu lintas. Namun UU No 22 Tahun 2009 belum secara implisit mengatur penerapan asas recklessness. Sehingga di lapangan pengaturannya masih mengacu kepada 359 KUHP, Pasal 360 KUHP serta Pasal 492 KUHP, dan bahkan untuk kasus-kasus yang sulit dan tidak ditemukan hukumnya di dalam UU lalu lintas, hakim menerapkan pasal $338 \mathrm{KUHP}$ dengan pertimbangan asas dolus eventualis untuk mengisi kekosongan hukum yang belum diatur di dalam UU lalu lintas. Berdasarkan hal itu di masa depan diperlukan reformulasi asas Recklessness dalam pembaharuan hukum lalu lintas berbasis nilai keadilan sosial Pancasila.
\end{abstract}

kata kunci : hukum, lalu lintas, pembaharuan, sembrono.

Pendahuluan.

Alinea keempat Pembukaan UUD NRI 1945, secara tegas menggariskan kepada Peme-rintah dalam menjalankan roda pemerintahan-nya selalu mengacu kepada tujuan utama pen-dirian Negara Kesatuan RI, yang meliputi: melindungi segenap bangsa dan seluruh tumpah darah Indonesia; memajukan kesejahteraan umum; mencerdaskan kehidupan bangsa; dan ikut melaksanaan ketertiban dunia berdasarkan kemerdekaan, perdamaian abadi dan keadilan sosial.

Tujuan negara sebagai arahan dan tolok ukur politik hukum nasional menekankan pentingnya perlindungan hukum bagi rakyat Indonesia dalam menjalankan aktivitas kehidupannya. Akan tetapi dewasa ini lahirnya undangundang sebagai alat pengatur kehidupan sosial cenderung belum dapat mencapai apa yang diamanatkan oleh konstitusi UUD Negara RI 1945 tersebut, untuk itu diperlukan upaya pembaharuan hukum terintegral dan komprehensif yang disesuaikan dengan dinamika kehidupan manusia sebagai objek pemberlakuan hukum. Sebab hukum merupakan resultante dari perubahan

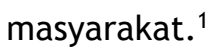

Manusia sebagai makhluk sosial memiliki kebebasan dan keinginan untuk terus berubah, bergerak dan berinteraksi antara satu dengan lainnya untuk memenuhi kebutuhan hidupnya. Disadari ataupun tidak disadari dalam menjalankan aktivitas tersebut manusia terkadang dihadapkan kepada berbagai macam resiko perjalanan, antara lain kecelakaan lalu lintas. 
Dewasa ini perangkat hukum terkait lalu lintas yang ada cenderung belum dapat menjadi sarana perekayasa perilaku tertib di jalan raya. Terbukti sebanyak 23.385 orang tewas dalam kecelakaan lalu lintas pada 2013. Antara lain disebabkan oleh faktor kesalahan manusia (human error). Kesalahan manusia (human error) dapat berupa perilaku kesembronoan atau recklessness. Asas recklessness dalam perspektif hukum pidana dapat menjadi parameter bagaimana bekerjanya hukum pidana lalu lintas di Indonesia.

Pembicaraan prinsip kesembronoan atau recklessness ini menjadi penting di tengah maraknya kasus kecelakaan lalu lintas yang diakibatkan oleh perilaku nekat atau sembrono para pengendara kendaraan di jalan raya. Sebagi contoh kasus kecalakaan maut yang dilakukan oleh Afriyani Susanti di Tugu Tani, Jakarta beberapa waktu lalu dan kasus kecelakaan maut di Tol Jagorawi yang dilakukan oleh AQJ alias Dul Putra Ahmad Dhani.

Penerapan asas recklessness dalam pembaharuan hukum pidana nasional menjadi sangat penting untuk menghindari kekosongan hukum dibidang lalu lintas dan menjadi pelengkap bagi penerapan asas kelalaian yang selama ini telah diformulasikan di dalam UU lalu lintas. Dengan begitu penegakan hukum lalu lintas sudah sesuai asas legalitas.

Penerapan UU Lalu Lintas 2009 sebagai sebuah bidang kajian cenderung memiliki keterbatasan, keterbatasan tersebut menyebabkan hukum pidana tidak mampu menjangkau sebab-sebab kejahatan yang kompleks dan berada di luar jangkauan hukum pidana, lagi pula hukum pidana hanyalah bagian kecil sarana kontrol sosial masyarakat yang dapat menjadi obat mujarab bagi keseluruhan persoalan kejahatan. ${ }^{2}$

Tulisan ini dimaksudkan untuk menjelaskan tentang penerapan Undang-Undang Lalu Lintas ketika dihadapkan kepada permasalahan recklessness dan solusi untuk menyelesaikan ma-

Agus Raharjo, "Problematika Asas Retroaktif dalam Hukum Pidana Indonesia”, Jurnal Dinamika Hukum, Vol. 8, No. 1, Edisi Januari 2008, Purwokerto: FH Unsoed, hlm. 71 salah melalui formulasi asas recklessness dalam sistem hukum pidana lalu lintas di kemudian hari.

\section{Eksistensi Asas Recklessness dalam Perspektif Asas Kelalaian dan Asas Dolus Eventualis.}

Arti kata lalai dalam kamus besar bahasa Indonesia berarti lengah, kurang ingat, tidak mengindahkan kewajiban atau pekerjaan, atau tidak sadar. Di dalam bahasa Ingris kata lalai disamakan dengan kata negligent yang berarti lalai, alpa, sembrono (recklessness), leka. Kata sembrono (recklessness) berarti suatu tindakan seorang secara gegabah, nekat, candang, yang cenderung melalaikan kewajiban serta akibatnya dapat membahayakan keselamatan orang lain.

Black's Law Dictionary mendefinisikan recklessness adalah sebagai berikut:

"A mental state characterized by a conscious and dangerous disregard of others' safety, resulting in creation of a substantial risk of harm. Recklessness amounts to a greater degree of fault than negligence". ${ }^{3}$

Seperti disebutkan dalam kamus hukum Black's Law Dictionary di atas bahwa pada prinsipnya tingkat unsur kesalahan yang terdapat di dalam asas kecerobohan (recklessness) lebih besar di banding asas kelalaian (negligence). Dengan demikian dapat diketahui mengapa penerapan asas kelalaian di dalam rumusan Pasal 310 UU Lalu Lintas cenderung mengalami kendala di lapangan, hal ini karena belum dirumuskannya asas kecerobohan (recklessness) di dalamnya.

Penerapan asas Recklessness dalam hukum pidana di Indonesia selama ini masih belum secara implisit diformulasikan. Seperti terlihat dalam Pasal 310 UU Lalu Lintas 2009

(1)Setiap orang yang mengemudikan Kendaraan Bermotor yang karena kelalaiannya mengakibatkan Kecelakaan Lalu Lintas dengan kerusakan Kendaraan dan/atau barang sebagaimana dimak-

Black's Law Dictionary Legal Dictionary 2nd Ed, “recklessness" tersedia di website http://thelawdictionary. org/recklessness-2/, diakses tanggal 2 September 2014 
sud dalam Pasal 229 ayat (2), dipidana dengan pidana penjara paling lama 6 (enam) bulan dan/atau denda paling banyak Rp 1.000.000,00 (satu juta rupiah);

(2)Setiap orang yang mengemudikan Kendaraan Bermotor yang karena kelalaiannya mengakibatkan Kecelakaan Lalu Lintas dengan korban luka ringan dan kerusakan Kendaraan dan/atau barang sebagaimana dimaksud dalam Pasal 229 ayat (3), dipidana dengan pidana penjara paling lama 1 (satu) tahun dan/atau denda paling banyak Rp 2.000.000,00 (dua juta rupiah);

(3) Setiap orang yang mengemudikan Kendaraan Bermotor yang karena kelalaiannya mengakibatkan Kecelakaan Lalu Lintas dengan korban luka berat sebagaimana dimaksud dalam Pasal 229 ayat (4), dipidana dengan pidana penjara paling lama 5 (lima) tahun dan/ atau denda paling banyak Rp10.000. 000,00 (sepuluh juta rupiah);

(4)Dalam hal kecelakaan sebagaimana di maksud pada ayat (3) yang mengakibatkan orang lain meninggal dunia, dipidana dengan pidana penjara paling lama 6 (enam) tahun dan/atau denda paling banyak Rp 12.000.000,00 (dua belas juta rupiah);

Selanjutnya asas kelalaian (negligence) juga ditemukan di dalam rumusan Pasal 58 ayat (1) UU N0. 36 tahun 2009 Tentang Kesehatan menyebutkan unsur kelalaian sebagai syarat penerapan ganti rugi bagi tenaga kesehatan, adapun bunyi selengkapnya sebagai berikut :

Setiap orang berhak menuntut ganti rugi terhadap seseorang, tenaga kesehatan, dan/atau penyelenggara kesehatan yang menimbulkan kerugian akibat kesalahan atau kelalaian dalam pelayanan kesehatan yang diterimanya. (Garis bawah dari penulis).

Politik hukum lalu lintas saat ini secara sub substansi hukum memformulasikan prinsip atau asas kelalaian (negligence) yang di dalamnya belum secara tegas mencakup asas sembrono (recklessness), meskipun demikian sebelum di undangkannya UU Lalu lintas tanggal 22 Juni 2009 pengaturan tentang pelanggaran lalu lintas telah di rumuskan di dalam Kitab Undang-undang Hukum Pidana yakni Pasal 359 KUHP, Pasal 360
KUHP serta Pasal 492 KUHP. Akan te-tapi seiring perkembangan jaman pengaturan di dalam KUHP tersebut dirasakan belum dapat menyelesaikan masalah dilapangan yang semakin kompleks.

Pasal 359 KUHP:

Barang siapa karena kesalahannya (kealpaannya) menyebabkan orang lain mati, diancam dengan pidana penjara paling lama lima tahun atau pidana kurungan paling lama satu tahun.

\section{Pasal 360 KUHP}

(1) Barang siapa karena kesalahannya (kealpaannya) menyebabkan orang lain mendapat luka-luka berat, diancam dengan pidana penjara paling lama lima tahun atau pidana kurungan paling lama satu tahun.

(2) Barang siapa karena kesalahannya (kealpaannya) menyebahkan orang lain luka-luka sedemikian rupa sehingga timbul penyakit atau halangan menjalankan pekerjaan jabatan atau pencarian selama waktu tertentu, diancam dengan pidana penjara paling lama sembilan bulan atau pidana kurungan paling lama enam bulan atau pidana denda paling tinggi empat ribu lima ratus rupiah.

\section{Pasal 492 KUHP}

(1) Barang siapa dalam keadaan mabuk di muka umum merintangi lalu lintas, atau mengganggu ketertiban, atau mengancam keamanan orang lain, atau melakukan sesuatu yang harus dilakukan dengan hati-hati atau dengan mengadakan tindakan penjagaan tertentu lebih dahulu agar jangan membahayakan nyawa atau kesehatan orang lain, diancam dengan pidana kurungan paling lama enam hari, atau pidana denda paling banyak tiga ratus tujuh puluh lima rupiah.

(2) Jika ketika melakukan pelanggaran belum lewat satu tahun sejak adanya pemidanaan yang menjadi tetap karena pelanggaran yang sama, atau karena hal yang dirumuskan dalam pasal 536, dijatuhkan pidana kurungan paling lama dua minggu.

Beberapa kasus lalu lintas yang menunjukkan kendala-kendala pelaksanaan asas recklessness di bidang lalu lintas dapat diperhatikan da- 
lam kasus-kasus berikut ini. Pertama, Putusan MA RI No. 1530. K/PID/1995, tanggal 30 Januari 1996 tentang kasus bus metro mini maut penerapan dolus eventualis untuk dijadikan yurisprudensi. Dalam pertimbangan disebutkan bahwa keadaan batin sang sopir tidak ambil peduli, berani ambil risiko, dengan sikapnya "Apa boleh buat", kalau akibat itu benar-benar terjadi (Teori In Kauf Nehmen). Perilaku sopir tersebut mencerminkan perilaku sembrono (recklessness) dan dengan sengaja mengabaikan aturan berlalu lintas yang berlaku saat itu.

Jadi, Perbuatan sopir yang demikian oleh hakim dikategorikan sebagai "Sengaja dengan sadar kemungkinan (dolus eventualis)" artinya si pembuat (sopir) dapat memperkirakan kemungkinan akan terjadinya suatu akibat, walau demikian, ia tidak menahan nafsunya untuk tidak melakukan perbuatan tersebut. Bertolak dari pertimbangan dan teori di atas, maka si sopir bus dalam kasus ini dinyatakan terbukti bersalah melakukan kejahatan "Pembunuhan" ex Pasal 338 KUHP dan "Penganiayaan” ex Pasal 351 (1) KUHP."

Berdasarkan putusan Mahkamah Agung tersebut dapat disimpulkan bahwa pada dasarnya setiap perbuatan untuk dapat dikenakan pidana harus memenuhi unsur kesalahan (mens rea) dan ada hubungan batin, seperti yang terdapat dalam asas sembrono mengandung tingkat kesalahan yang disengaja (dolus) yang lebih tinggi daripada kelalaian (negligence) atau kealpaan (alpa), artinya semua perbuatan segala resiko dan akibatnya telah diketahui, namun tetap dijalankan termasuk dalam kategori asas recklesssness dan bukan merupakan kelalaian (negligence).

Kedua, Putusan Pengadilan Tinggi DKI No. 47/PID/2013/PT.DKI dalam kasus kecelakaan maut di Tugu Tani Jakarta yang dilakukan oleh terdakwa Afriyani Susanti yang dengan sembrono (recklessness) mengendarai mobil minibus dalam keadaan mabuk dibawah pengaruh minuman keras dan narkotika, sehingga mengakibatkan sembilan orang meninggal dunia. Penerapan asas recklessness dalam kasus tersebut dapat diperhatikan dalam pertimbangan Putusan Ban- ding Pengadilan Tinggi Tersebut didasarkan atas pertimbangan yang antara lain sebagai berikut: (a) Menimbang, bahwa berdasarkan fakta-fakta hukum yang terungkap dalam persidangan tersebut, telah membuktikan bahwa terdakwa telah melakukan perbuatan sebagaimana yang diuraikan dalam dakwaan Subsidair dan dengan demikian berdasarkan fakta hukum tersebut telah cukup membuktikan hukum perbuatan terdakwa telah memenuhi seluruh unsur-unsur yang terkandung dalam pasal 127 ayat (1) huruf a UURI No. 35 Tahun 2009 tentang Narkotika, karena itu kesimpulan dan pendapat Majelis Hakim Tingkat Pertama yang menyatakan perbuatan terdakwa terbukti bersalah melakukan tindak pidana yang diatur dalam pasal 127 ayat (1) huruf a UURI No. 35 Tahun 2009; (b) Menimbang, bahwa selama berlangsung pemeriksaan perkara juga tidak terdapat hal-hal yang dapat dijadikan sebagai alas pemaaf pada diri terdakwa, hal demikian membuktikan bahwa terdakwa adalah orang yang mampu bertanggung jawab atas perbuatannya, karena itu sudah tepat dan benar bilamana kepada terdakwa dijatuhi pidana penjara.

Berdasarkan hal tersebut, pengadilan memutuskan seagai berikut: menerima permintaan banding dari Penasihat Hukum Terdakwa dan Penuntut Umum; menguatkan putusan Pengadilan Negeri Jakarta Barat No. 1142/PID.SUS/2012/ PN.JKT.BAR tanggal 19 Desember 2012 yang dimintakan banding tersebut; memerintahkan Terdakwa ditahan; dan membebankan Terdakwa untuk membayar biaya perkara dalam kedua tingkat pengadilan, yang dalam tingkat banding sebesar Rp. 2.500,- (dua ribu lima ratus rupiah). Berdasarkan pertimbangan majelis hakim tersebut dapat di tarik kesimpulan bahwa penerapan asas kesembronoan (recklessness) masih belum menjadi pertimbangan hukum dalam tindak pidana kejahatan lalu lintas begitu pula dengan asas kelalaian (negligence) yang nyata-nyata telah diformulasikan di dalam UU Lalu Lintas.

Ketiga, Putusan Pengadilan Negeri pada tanggal 16 Juli 2014 terhadap AQJ alias Dul putra Ahmad Dhani dalam perkara tabarakan maut di jalan Tol Jagorawi 8 September 20013 yang 
menewaskan tujuh orang tersebut dalam amar putusan hakim disebutkan sebagai berikut.

Disebutkan bahwa AQJ dijatuhi vonis bersalah melanggar Pasal 310 ayat 4, 310 ayat (3), dan 310 ayat 1 dalam Undang-Undang Lalu Lintas dan Angkutan Jalan. Hakim membebaskan Dul dari hukuman. Majelis Hakim memutuskan agar Dul dikembalikan kepada kedua orangtuanya, Ahmad Dhani dan Maia Estianti. Adapun hal yang meringankan adalah Dul berlaku sopan dan berbudi baik selama proses persidangan. "Terdakwa bukan anak yang nakal, tetapi hanya kurang perhatian orangtua. Terdakwa masih dapat dibina," ujar hakim.

Hakim juga menyatakan bahwa telah terjadi perdamaian antara keluarga Dul dan keluarga korban. Keluarga terdakwa juga bersedia bertanggung jawab untuk menanggung biaya rumah sakit, perawatan, dan pemakaman untuk korban meninggal serta biaya pendidikan anak para korban hingga perguruan tinggi. Pertimbangan lainnya, yakni pergantian Undang-Undang Nomor 3 Tahun 1997 tentang Peradilan Anak untuk menyongsong pemberlakukan undang-undang yang baru, UU Nomor 11 Tahun 2014. Hakim mengacu pada restorative justice pada undang-undang baru tersebut yang dinilai telah terpenuhi dalam perkara Dul.

Berdasarkan putusan AQJ di atas dapat disimpulkan bahwa penerapan asas kesembronoan (recklessness) dalam penegakan hukum lalu lintas di Indonesia masih belum diformulasikan secara khusus, sehingga masih ada kekosongan hukum yang dapat menjadi celah bagi pelaku kejahatan lalu lintas. Meskipun dalam penerapan hukum lalu lintas sudah ditekankan asas kelalaian.

Berangkat dari kasus-kasus tersebut dapat ditarik benang merah bahwa secara substansial suatu perbuatan dianggap memenuhi asas sembrono (recklessness) bila di dalam jiwa atau mental pelaku terdapat kesadaran atau hubungan batin yang dapat dipertanggungjawabkan sebagai bentuk kesengajaan atau kealpaan atau telah lalai bahwa perbuatannya merupakan ka-

4 Moeljatno, 2008, Asas-Asas Hukum Pidana, Jakarta: Rineka Cipta, hlm. 188-189 tegori perbuatan melawan hukum hingga berakibat meninggalnya orang lain. Khusus kasus "AQJ atau Dul" tentu diperlukan pertimbangan khusus dari pegak hukum secara progresif, mengingat ia masih anak-anak.

Recklessness dalam persepektif asas dolus eventualis seperti disebutkan didalam kasus metro mini di atas dapat dianalisis bahwa dalam pandangan Mexger mengkatagorikan di dalam teori inkauf nehmen (op den koop toe nemen) dolus eventualis atau teori "apa boleh buat". ${ }^{4}$ Artinya sembrono (recklessness) adalah sebagai bentuk kesengajaan yang dilakukan subjek hukum dan menginsafinya akan akibat yang ditimbulkan kemudian. Sehingga sembrono (recklessness) ini termasuk ke dalam kategori kesengajaan (dolus).

Berdasar perspektif asas kesengajaan dengan sadar kemungkinan (dolus eventualis), apabila seseorang melakukan suatu perbuatan dengan tujuan atas akibat tertentu akan tetapi si pelaku menyadari bahwa kemungkinan akan timbul akibat lain, yang juga diancam dan dilarang undang-undang. Menurut Van Bemmelen menyebut bentuk dolus eventualis dengan "sengaja bersyarat", sebagai berikut:

"Sengaja bersyarat bertolak dari kemungkinan. Maka tidak pernah lebih banyak dikehendaki dan diketahui daripada kemungkinan itu. Seseorang yang menghendaki kemungkinan matinya orang lain, tak dapat dikatakan bahwa ia menghendaki supaya orang itu mati. Tetapi jika seseorang melakukan suatu tindakan dengan kesadaran bahwa perbuatannya akan dapat menyebabkan matinya orang lain, ia memang menunjukkan bahwa ia menghendaki kematian orang itu." 5

Berkaitan dengan kesengajaan tipe dolus eventualis ini, P.A.F. Lamintang, mengenai mengemukakan bahwa:

"Pelaku yang bersangkutan pada waktu ia melakukan perbuatannya untuk menimbulkan suatu akibat yang dilarang oleh undang-undang telah menyadari kemungkinan akan timbulnya suatu akibat yang lain daripada akibat yang memang ia kehendaki. Jadi, jika kemungkinan yang ia sadari

$5 \quad$ Ibid., hlm. 17 
itu kemudiaan menjadi kenyataan, maka terhadap kenyataan tersebut, ia dikatakan mempunyai suatu kesengajaan."6

Untuk menerangkan adanya kesengajaan dengan sadar kemungkinan (dolus eventualis), jika dipakai teori kehendak (wilstheorie), maka keterangannya:

"Jika pembuat menetapkan dalam batinnya, bahwa ia lebih menghendaki perbuatan yang dilakukan itu, meskipun nanti akan ada akibat yang tidak ia harapkan daripada tidak berbuat, maka kesengajaan orang tersebut juga ditujukan kepada akibat yang tidak diharapkan itu."

Jika dipakai teori pengetahuan/membayangkan (voorstellings-theori), maka penjelasannya:

"Jika si pembuat mengetahui/membayangkan akan kemungkinan terjadinya akibat yang tak dikehendaki, tetapi bayangan itu tidak berbuat; maka dapat dikatakan bahwa kesengajaan diarahkan kepada akibat yang mungkin terjadi itu. ${ }^{7}$

Untuk perbuatan pidana yang dapat dikategorikan sebagai suatu Kesengajaan di dalam teori hukum pidana diperlukan dua syarat. Pertama, subjek mengetahui kemungkinan adanya akibat keadaan yang timbul kemudian merupakan delik; dan kedua, sikapnya terhadap kemungkinan itu andaikata sungguh timbul, ialah boleh buat, dapat disetujui dan berani memikul resiko hukum yang terjadi kemudian.

Jadi dapat disimpulkan bahwa kategori suatu perbuatan dianggap sengaja bila mana subjek tersebut dalam menjalankan perbuatannya diinsafi atau tidak diinsafi terhadap akibat dan keadaan yang menyertainya. Dalam teori hukum pidana ada tiga jenis kesengajaan yaitu: kesengajaan sebagai maksud; kesengajaan sebagai kepastian, keharusan; dan dolus eventualis.

Terkait lalai atau sembrono dipandang dari sisi kealpaan, menurut Langemeyer mengatakan bahwa:

"kealpaan adalah suatu struktur yang sangat gecompliceerd. Mengandung dalam satu pihak kekeliruan dalam perbuatan lahir, dan menunjuk kepada adanya keadaan batin yang tertentu, dan di lain pihak keadaan batinnya itu sendiri...dengan demikian culpa mencakup semua makna kesalahan dalam arti luas yang bukan berupa kesengajaan. Beda kesengajaan dengan kealpaan adalah bahwa dalam kesengajaan ada sifat positif berupa kehendak dan penyetujuan yang disadari dari bagian-bagian delik yang meliputi kesengajaan. Di mana sifat positif ini tidak ada dalam kealpaan. Oleh karena itu dapatlah dimengerti bahwa dipakai istilah yang sama untuk kesalahan dalam arti yang luas dan kesalahan dalam arti sempit, meskipun ini tidak praktis.

Simons menyebutkan bahwa isi kealpaan adalah tidak adanya penghati-hatian di samping dapat diduga-duga akan timbul akibat. Jadi terkait, tindakan sembrono (recklessness) di bidang lalu lintas dapat juga dikatakan sebagai kealpaan atau kelalaian yang disadari (bewuste culpa) oleh subjeknya.

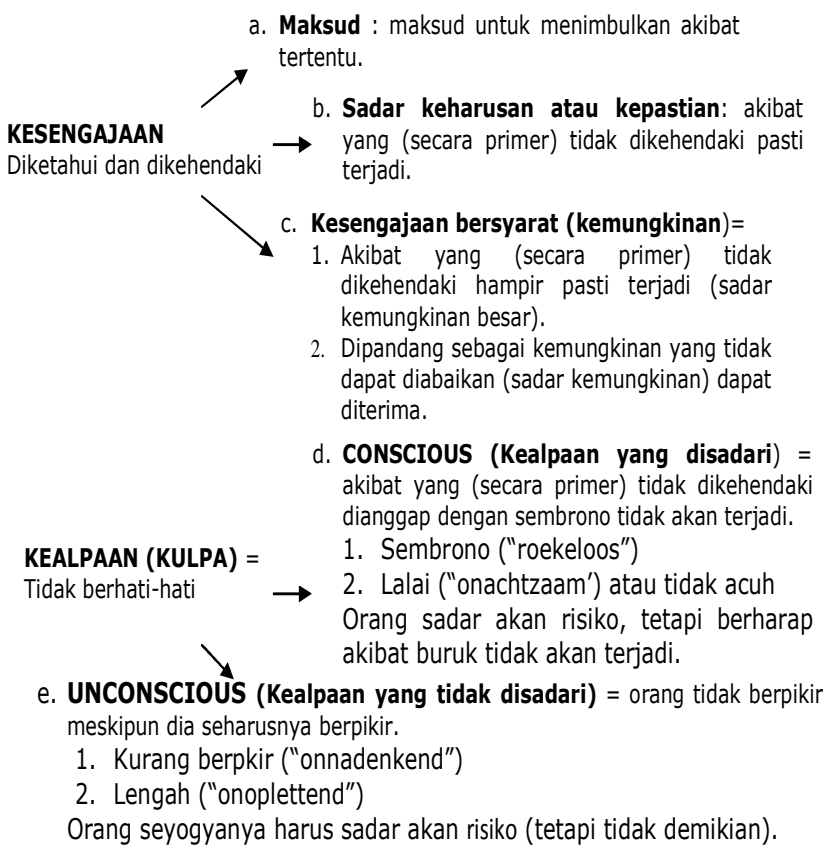

\section{Bagan 2. Struktur Pembagian Kesalahan}

Pada umumnya, sengaja adalah menghendaki, sedang kealpaan tidak menghendaki. Kealpaan adalah satu bentuk "kesalahan" yang lebih ringan dari sengaja. Itulah sebabnya ancaman hukuman pelanggaran-pelanggaran pidana yang dilakukan dengan kealpaan lebih ringan. 
Kesalahan mempunyai arti yang masingmasing berbeda jangkauan dan isinya. Pertama, kesalahan dalam arti seluas-luasnya, da-at disamakan dengan pengertian "pertanggungjawaban dalam Hukum Pidana", di dalamnya terkandung makna dapat dicelanya (verwijtbaarheid) si pembuat atas perbuatannya. Jadi apabila dikatakan, bahwa orang yang bersalah melakukan suatu tindak pidana, maka itu berarti bahwa ia dapat dicela atas perbuatannya. Kedua, kesalahan dalam arti bentuk kesalahan (schuldvorm) yang berupa: kesengajaan (dolus, opzet, vorsatz atau intention); atau kealpaan (culpa, onachtzaamheid, nelatigheid, farlassigkeit atau negligence). Ini pengertian kesalahan yuridis. Ketiga, kesalahan dalam arti sempit, ialah kealpaan (culpa) seperti yang disebutkan di atas. Pemakaian istilah "kesalahan" dalam arti ini sebaiknya dihindarkan dan digunakan saja istilah "kealpaan."

\section{Asas Recklessness dalam Perspektif Asas Le- galitas}

Asas sembrono (recklessness) dalam perspektif asas legalitas dalam penegakan hukum lalu lintas merupakan syarat mutlak untuk penjatuhan pidana. Seperti dikemukakan oleh Satjipto Raharjo, penegakan hukum di suatu negara sebaiknya dilihat sebagai suatu proses interaktif. Artinya, apa yang dipertontonkan kepada kita sebagai hasil dari penegakkan hukum itu janganlah diterima sebagai hasil dari penegakan hukum itu sendiri, melainkan suatu hasil dari bekerjanya proses saling mempengaruhi di antara berbagai komponen yang terlihat di situ, seperti penegak hukum itu sendiri, peraturanperaturan yang ada, para anggota masyarakat, sarana fisik yang tersedia dan lain-lainnya. ${ }^{8}$

Asas legalitas dimaksudkan untuk melindungi kepentingan hak-hak warga negara dari pendefinisian perbuatan pidana yang dilakukan secara sewenang-wenang. Untuk mencegah pendefinisian yang sewenang-wenang ini, maka

\footnotetext{
8 Budiyono, "Peran Bank Indonesia dalam Penanggulangan Tindak Pidana Perbankan”, Jurnal Dinamika Hukum, Vol. 11 Edisi Khusus Februari 2011, Purwokerto: FH Unsoed, hlm. 118-119

9 Deni SB Yuherawan, "Kritik Ideologis Terhadap Dasar Ke-
}

pendefinsian harus dilakukan dengan undangundang pidana. Pendefinisian perbuatan pidana dengan undang-undang mempunyai makna ganda. Pertama, tidak ada suatu penuntutan jika suatu perbuatan tidak dinyatakan sebagai mala prohibita ini berarti crimina extra ordinaria tidak akan dituntut, dan kedua, harus dilakukan penuntutan terhadap mala prohibita, karena warga negara dianggap tahu dan mau menerima resiko dari perbuatan yang dilakukan. Asas legalitas hanya berorientasi kepada hak-hak dan kepentingan pelaku (offender oriented). Pelaku tidak akan dituntut jika perbuatannya bukan merupakan mala prohibita. Secara aksiologis, Asas legalitas hanya memberikan nilai manfaat kepada pelaku. ${ }^{9}$

Sejarah Asas legalitas tersebut kali pertama diucapkan oleh sarjana hukum Jerman von Feuerbach (1775-1833), Nullum delictum nulla poena sine praevia lege. Yang ternyata asas legalitas sebelumnya telah dituliskan di dalam buku Mostesquieu, L'esprit des Lois (1748) dan buku Rousseau, Die Contract Social (1762). Selanjutnya asas tersebut dirumuskan sebagai wet atau Undang-Undang Dasar di era Revolusi Perancis, seperti ternyata pada rumusan Pasal 8 Declaration des droits de L'homme et du citoyen (1789). Kemudian di masa pemerintahan Napoleon (1801) asas tersebut dirumuskan ke dalam Pasal 4 Code Penal Perancis. Sedangkan di Nederlands yang ketika itu sebagai jajahan Napoleon, asas legalitas dirumuskan di dalam Pasal 1 Wetboek v.Strafrecht Nederlands 1881. Akhirnya akibat adanya asas konkordansi antara Nederlands Indie dan Nederlans, maka asas legalitas dimasukkan ke dalam Pasal 1 W.v.S Nederlands Indie $1918 .{ }^{10}$ Asas legalitas atau asas pertanggungjawaban pidana adalah: tidak dipidana jika tidak ada kesalahan (Geen Straf Zonder schuld; Actus non facit reum nisi mens sit rea), sebaliknya, pertanggungjawaban tanpa adanya kesalahan bagi yang melanggar disebut

filsafatan Asas Legalitas Dalam Hukum Pidana", Jurnal Dinamika Hukum Vol. 12 No. 2, Edisi Mei 2012, Purwokerto: FH Unsoed, hlm. 224

10 Ibid, hlm. 25-27. 
leer van het materiele feit atau fait materielle. ${ }^{11}$

Penggunaan kata lalai secara implisit belum menegaskan adanya sikap batin dari perbuatan subjek di atas yang sembrono (recklessness), sehingga bila hal ini terus berlangsung dikhawatirkan dapat menjadi celah terjadinya kekosongan hukum pidana lalu lintas. Kata bersayap demikian di dalam hukum pidana sangat tidak dianjurkan dan bertentangan dengan asas legalitas (principle of legality) dari hukum pidana Pasal 1 ayat (1) KUHP, yaitu asas yang menegaskan bahwa:

Tiada suatu perbuatan dapat dipidana kecuali atas kekuatan aturan pidana dalam perundang-undangan yang telah ada, sebelum perbuatan dilakukan.

Menurut Moeljatno, asas legalitas biasanya mengandung tiga pengertian. Pertama, tidak ada yang dilarang dan diancam pidana bila belum diatur oleh undang-undang; kedua, untuk menentukan ada atau tidaknya suatu perbuatan pidana, tidak boleh digunakan analogi atau kias; dan ketiga, aturan pidana tidak berlaku surut. ${ }^{12}$

Kesalahan merupakan hubungan antara keadaan batin dengan perbuatannya yang menimbulkan pidana dianggap sempurna bila perbuatan subjek telah memenuhi unsur perbuatan yang disengaja (dolus) atau kealpaan (culpa). Simons menekankan suatu delik dapat diukur dari penilaian dari hubungan batin dan perbuatan subjek di dalam delik. Artinya untuk dapat menentukan adanya kesalahan yang dapat dipidana, maka perbuatan subjek harus memenuhi tiga hal. Pertama, ada unsur perbuatan melawan hukum (onrechtmatigdaad) atau perbuatan pidana; kedua, mampu bertanggung jawab diukur berdasarkan umur subjek; ketiga, perbuatan subjek memenuhi kriteria kesengajaan (dolus) atau kealpaan (culpa); dan keempat, tidak ada alsan pemaaf. Dalam perspektif prinsip sikap melawan hukum yang muncul di Jerman diprakasai oleh Mazger, von Weber Welel, Muarach, dan Busch, kemudian apakah kata lalai sudah mencerminkan sikap batin seorang atau subjek ketika melakukan perbuatan pidana atau sebagai unsur melawan hukum yang sub-jektif (Subjektif Onrechtselement) untuk menjatuhkan pidana.

Pasal 310 ayat (4) tersebut sebagai Lex Specialis dari Pasal 359 KUHP. Pada PP No. 37 tahun 2011 tentang Forum Lalu Lintas dan Angkutan Jalan juga tidak mengatur secara khusus pasal mengenai kealpaan (culpa) yang menyebabkan matinya orang lain, namun hanya diatur mengenai penegakan hukum meliputi penindakan pelanggaran dan penanganan kecelakaan lalu lintas yang sama-sama termuat dalam Pasal 12 huruf (f) UU No. 22 tahun 2009 dan Pasal 8 huruf (f) PP No. 37 tahun 2011. Dalam hal pemberian sanksi dapat diberikan jika ditemukan unsur-unsur tindak pidana dalam Pasal $359 \mathrm{KU}$ HP. Mengenai tanggung jawab pelaku terhadap korban diatur dalam Pasal 235 ayat (1) UU No. 22 Tahun 2009, sedangkan UU Lalu Lintas sebelumnya UU No. 14 tahun 1992 mengaturnya dalam Pasal 28 dan Pasal 31 ayat (1). Sedangkan pada Pasal 316 ayat (1) dan ayat (2) UU No. 22 Tahun 2009 menyebut pasal-pasal yang termasuk kualifikasi delik kejahatan dan pelanggaran, dan untuk Pasal 310 termasuk delik kejahatan. Terkait dengan penjatuhan pidana, masih terdapat kekosongan pasal yang memuat batasan yuridis atau pedoman yang jelas mengenai perbuatan yang dianggap lalai (kealpaan) dan sembrono (recklessnessness). Istilah kealpaan (negligence) dan sembrono (recklessness) seringkali disamaratakan. Mencermati beberapa kasus di Indonesia seperti halnya, seharusnya masuk recklessnessness atau kesengajaan dengan sadar kemungkinan (dolus eventua(is) bukan negligence. Terhadap kasus tersebut dasar memutusnya bisa berpedoman pada

Suatu kelalaian dalam hukum pidana, merujuk kepada kekurangcermatan, kurang pengetahuan, dan bertindak kurang terarah. Fungsionalisasi hukum mengatur tentang kelalaian ini semata-mata untuk memberikan perlindungan terhadap kebendaan (kepentingan) hukum tertentu melalui kebijakan hukum pidana. Dalam berlalu lintas, kepentingan hukum yang hendak 
dilindungi adalah keamanan pengguna jalan raya terhadap kemungkinan risiko terancam bahaya oleh pengemudi kendaraan yang tidak berhati-hati. Jadi, tujuan pemidanaan yang hendak dicapai lebih kepada sisi prefensi umum, atau peringatan kepada khalayak umum agar selalu berhati-hati dalam berlalu lintas.

\section{Recklessness dalam Pembaharuan Hukum Berlalu Lintas Berbasis Budaya Hukum.}

Secara umum fakta fisik menunjukkan bahwa angka kecelakaan lalu lintas di Indonesia cenderung semakin meningkat, salah satunya disinyalir disebabkan oleh faktor human error atau kesalahan manusia di antaranya perilaku sembrono (Recklessness) dari manusia, perilaku semacam itu merupakan cermin budaya berlalu lintas masyarakat yang masih rendah.

Tabel

Jumlah Kecelakaan, Koban Mati, Luka Berat, Luka Ringan, dan Kerugian Materi yang Diderita Tahun 1992-2012

\begin{tabular}{|c|r|r|r|r|r|}
\hline Tahun & $\begin{array}{c}\text { Jumlah } \\
\text { Kecela- } \\
\text { kaan }\end{array}$ & $\begin{array}{c}\text { Korban } \\
\text { Mati }\end{array}$ & $\begin{array}{c}\text { Luka } \\
\text { Berat }\end{array}$ & $\begin{array}{c}\text { Luka } \\
\text { Ringan }\end{array}$ & $\begin{array}{c}\text { Kerugia } \\
\mathbf{n} \\
\text { Materi } \\
\text { (Jt Rp) }\end{array}$ \\
\hline 1992 & 19920 & 9819 & 13363 & 14846 & 15077 \\
\hline 1993 & 17323 & 10038 & 11453 & 13037 & 14714 \\
\hline 1994 & 17469 & 11004 & 11055 & 12215 & 16544 \\
\hline 1995 & 16510 & 10990 & 9952 & 11873 & 17745 \\
\hline 1996 & 15291 & 10869 & 8968 & 10374 & 18411 \\
\hline 1997 & 17101 & 12308 & 9913 & 12699 & 20848 \\
\hline 1998 & 14858 & 11694 & 8878 & 10609 & 26941 \\
\hline $\left.1999^{*}\right)$ & 12675 & 9917 & 7329 & 9385 & 32755 \\
\hline 2000 & 12649 & 9536 & 7100 & 9518 & 36281 \\
\hline 2001 & 12791 & 9522 & 6656 & 9181 & 37617 \\
\hline 2002 & 12267 & 8762 & 6012 & 8929 & 41030 \\
\hline 2003 & 13399 & 9856 & 6142 & 8694 & 45778 \\
\hline 2004 & 17732 & 11204 & 8983 & 12084 & 53044 \\
\hline 2005 & 91623 & 16115 & 35891 & 51317 & 51556 \\
\hline 2006 & 87020 & 15762 & 33282 & 52310 & 81848 \\
\hline 2007 & 49553 & 16955 & 20181 & 46827 & 103289 \\
\hline 2008 & 59164 & 20188 & 23440 & 55731 & 131207 \\
\hline 2009 & 62960 & 19979 & 23469 & 62936 & 136285 \\
\hline 2010 & 66488 & 19873 & 26196 & 63809 & 158259 \\
\hline 2011 & 108696 & 31195 & 35285 & 108945 & 217435 \\
\hline 2012 & 117949 & 29544 & 39704 & 128312 & 298627 \\
\hline
\end{tabular}

Sumber : Kantor Kepolisian Republik Indonesia

Fakta fisik menunjukkan bahwa jumlah korban kecelakaan lalu lintas sampai dengan tahun 2013 masih relatif tinggi meskipun cenderung menunjukkan penurunan sebesar $20,66 \%$ dibanding tahun 2012 yang mencapai 117.949 kasus dengan perincian sebagai berikut. Pertama, korban meninggal dunia selama tahun 2013 sebanyak 23.385 orang, sedangkan tahun 2012 sebanyak 29.544 orang, sehingga mengalami penurunan sebesar 20,84\%; kedua, korban luka berat dalam kecelakaan lalu lintas di tahun 2013, sebanyak 27.054 orang atau turun sebesar 31,66\% dibanding tahun 2012 lalu yang mencapai 39.704 orang; ketiga, korban luka ringan selama tahun 2013, yakni sebanyak 104.976 orang, sedangkan di tahun 2012 lalu mencapai 128.312 orang, dengan demikian, korban luka ringan akibat kecelakaan lalu lintas menurun 18,18\%; dan keempat, kerugian materiil akibat kecelakaan lalu lintas selama tahun 2013 sebesar Rp. 233. 842.283.566. Turun dari tahun 2012 sebesar Rp. 298.627.130.430,

Bertolak dari masih banyaknya tingkat kecelakaan lalu lintas di Indonesia tersebut, maka diperlukan upaya pembaharuan hukum pidana lalu lintas berbasis budaya tertib dan hati-hati. Budaya hukum dalam pandangan aliran historis Carl von Savigny (1779-1861) merupakan instrumen yang paling efektif diaplikasikan langsung di tengah-tengah kehidupan masyarakat untuk mewujudkan kesejahteraan karena 'ia' telah lama hidup dan berkembang di dalam kehidupan masyarakat jauh sebelum tatanan hukum tertulis ada, artinya tatanan hukum mengandung hukum kebiasaan di samping hukum statuta, maka di samping norma-norma kostitusi tertulis, seharusnya juga ada norma-norma konstitusi tidak tertulis, suatu norma yang dibentuk menurut kebiasaan atau budaya yang melandasi pembentukan norma-norma umum yang mengikat organ penegak hukum. Hukum cermin budaya masyarakat, alat untuk menegakkan ketertiban yang sifatnya konservatif (memelihara) serta alat untuk membangun (mengarahkan) masyarakat agar lebih maju.

Mengingat Indonesia adalah negara hukum yang bertujuan untuk melindungi setiap orang dari tindakan kesewenang-wenangan dalam setiap interaksi sosial. Maka upaya penegakan hukum lalu lintas melalui hukum pidana mempunyai peran penting dalam menciptakan ketertiban berlalu lintas, hukum sebagai alat rekayasa sosial (law as a tool social engeneering) meliputi 
perumusan tindak pidana (criminal act), pertanggungjawaban pidana, dan sanksi (sanction) baik pidana maupun tata-tertib. Sesuai dengan tujuan yang tidak hanya sebagai alat ketertiban. Artinya pembuatan, penerapan dan penegakan hukum lalu lintas memiliki tujuan untuk pembaharuan masyarakat (social engineering). ${ }^{13}$

UU lalu lintas di dalamnya terkandung asas-asas hukum pidana yang mendasari pembuatan hukum atau legal policy, hal ini mengandung arti bahwa pembuatan hukum lalu lintas adalah bertujuan untuk mewujudkan keadilan sesuai teori etis bahwa tujuan hukum sematamata untuk mewujudkan keadilan (justice) dan juga untuk mencapai kemanfaatan dan kepastian hukum seperti ditekankan dalam teori modern. ${ }^{14}$ Sejalan dengan itu, tujuan hukum dalam pandangan Gustav Radbruch (1978 -1949) adalah meliputi keadilan, kegunaan dan kepastian hukum.

Secara sosiologis hukum menjadi sarana untuk tercapainya keadilan dan ketertiban masyarakat serta harus mencerminkan aspek filosofis, yuridis, sosiologis dan historis sehingga kehidupan bangsa dan negara harus berkesinambungan. Meskipun tidak dapat dipungkiri bahwa membicarakan hukum di tingkat implementasinya, maka kesadaran utama yang harus dimunculkan adalah, ketika hukum sudah diimplementasikan di masyarakat, maka hukum hanya merupakan salah satu sub-sistem di dalam masyarakat. Masih ada sub-sistem lain yang bekerja di masyarakat, seperti sub-sistem politik, sub-sistem ekonomi, sub-sistem budaya, sub-sistem agama dan sejenisnya. Dengan demikian berlakunya aturan hukum itu pun akan terpengaruh oleh sub-sistem yang lain. ${ }^{15}$

Berkaitan dengan pengertian pembaharuan hukum pidana Barda Nawawi Arief mengemukakan: ${ }^{16}$

Pembaharuan hukum pidana pada hakikatnya mengandung makna suatu upaya un-

13 So Woong Kim, “Kebijakan Hukum Pidana dalam Upaya Penegakan Hukum Lingkungan Hidup”, Jurnal Dinamika Hukum Vol. 13 No. 3, Edisi September 2013, Purwokerto: FH Unsoed, hlm.418

14 Inge Dwisvimiar, "Keadilan dalam Perspektif Ilmu Hukum”, Jurnal Dinamika Hukum Vol. 11 No. 3, Edisi September 2011, Purwokerto: FH Unsoed, hlm. 529-530. tuk melakukan reorientasi dan reformasi hukum pidana yang sesuai dengan nilai-nilai sentral sosio-politik, sosio-filosofik, dan sosio-kultural masyarakat Indonesia yang melandasi kebijakan sosial, kebijakan kriminal, dan kebijakan penegakkan hukum di Indonesia.

Pembaharuan hukum pidana (termasuk hukum pidana formil), harus ditempuh melalui pendekatan yang berorientasi pada kebijakan ("policy-oriented approach"), karena memang pada hakikatnya ia hanya merupakan bagian dari suatu langkah kebijakan atau "policy" (yaitu bagian dari politik hukum/penegakan hukum, politik hukum pidana, politik kriminal, dan politik sosial), dan sekaligus pendekatan yang berorientasi pada nilai (value-oriented approach), karena dalam setiap kebijakan (policy) terkandung pula pertimbangan nilai.

Politik hukum pidana nasional secara komprehensif dan integral meliputi subsistem substansi hukum, struktur hukum, dan budaya hukum di bidang lalu lintas di masa depan sudah semestinya dilakukan dan disenergikan dengan semangat Pancasila yang corenya adalah nilai kedilan sosial dan prinsip-prinsip hak asasi manusia yang tercakup di dalam Pasal 28 UUDNRI 1945. Artinya apabila hukum pidana akan dilibatkan dalam usaha-usaha mengatasi segi negatif perkembangan masyarakat, maka selayaknya diperhatikan dalam relasi keseluruhan politik kriminal atau social defense planning, yang merupakan bagian terintegral dari rencana pembangunan nasional di segala bidang, sebagai bentuk nyata dari upaya penanggulangan kejahatan seperti diungkapkan oleh G.P.Hoefnagels, meliputi: penerapan hukum pidana (criminal law application), pencegahan tanpa pidana (preverention without punishment), mempengaruhi pandangan masyarakat tentang kejahatan (khususnya kejahatan yang ditimbulkan oleh perilaku sembrono/recklessness), dan pemidanaan mela-

5 FX.Adji Samekto, "Relasi Hukum dengan Kekuasaan: Melihat Hukum Dalam Perspektif Realitas", Jurnal Dinamika Hukum, Vol. 13 No. 1, Edisi Januari 2013, Purwokerto: FH Unsoed, hlm. 90.

16 Barda Nawawi Arief, 2010, Bunga Rampai Kebijakan Hukum Pidana (Perkembangan Penyusunan Konsep KUHP Baru), Jakarta: Kencana, hlm. 27. 
lui media masa (influencing views of society on crime and punishment/mass media). ${ }^{17}$ Khususnya dalam rangka penanggulangan tindak pidana kejahatan yang tersamarkan oleh perilaku sembrono (recklessness).

Pembaharuan atau politik hukum pidana nasional di bidang lalu lintas harus selalu mencerminkan nilai-nilai atau aspirasi sosio-filosofik dan sosio kultural yang ada di masyarakat. Yakni dengan memperhatikan berbagai aspek pengaruhnya antara lain aspek kebijakan kriminalisasi (formulasi tindak pidana) dan aspek pertanggungjawaban pidana (kesalahan/mens rea) serta aspek pemidanaan ${ }^{18}$. Oleh karena itu, dalam upaya pembaharuan atau politik hukum pidana (KUHP) nasional setiap proses tahapannya (tahap kebijakan legislatif/formulatif; tahap kebijakan yudikatif/aplikatif; dan tahap kebijakan eksekutif/administratif) seyogyanya perlu dilakukan pengkajian dan penggalian nilai-nilai nasional yang bersumber pada Pancasila dan nilainilai yang ada di masyarakat (nilai-nilai religius maupun nilai-nilai budaya/adat). ${ }^{19}$

Pembaharuan hukum pidana di Indonesia menyangkut tiga persoalan pokok, yaitu perbuatan, orang, dan pidana (sanksi) bagi yang melakukan perbuatan terlarang. Dilihat dari sudut dogmatis normatif, substansi atau masalah pokok dari hukum pidana (material) terletak pada persoalan tentang perbuatan apa yang sepatutnya di pidana, syarat apa yang harus dipenuhi untuk mempertanggungjawabkan seseorang, dan sanksi (pidana) apa yang sepatutnya dijatuhkan. Dengan demikian, ketiga masalah pokok itu secara singkat biasa disebut tindak pidana, kesalahan, dan pidana. ${ }^{20}$

Pelanggaran hukum terjadi karena lemahnya diseminasi dan penyuluhan hukum menjadi bagian dari tanggung jawab penyelenggara ne-

17 Saiful Abdullah, "Kebijakan Hukum Pidana (Penal) dan Non Hukum Pidana (Non Penal) dalam Menanggulangi Aliran Sesat", Jurnal Pembaharuan Hukum, Vol. 4 No. 1, Edisi April 2009, Semarang: Program Magister Ilmu Hukum, Pascasarjana Universitas Diponegoro Semarang, hlm. 96-97.

18 Tuti Budhi Utami, "Kebijakan Hukum Pidana dalam Menanggulangi Tindak Pidana Illegal Logging", Jurnal Pembaharuan Hukum, Vol. 3 No. 2, Edisi Oktober 2007, Semarang: Program Magister Ilmu Hukum, Pascasarjana Universitas Diponegoro Semarang, hlm.104.

19 Ibid, hlm. 8 gara. Pelaksanaan diseminasi dan penyuluhan hukum adalah unsur yang tidak dapat dipisahkan dari penerapan asas fiksi hukum yang menyatakan bahwa "setiap orang dianggap tahu hukum". Kaitannya dengan tindakan law enforcement dalam semua faktor hukum harus selalu dibarengi dengan upaya preventif berbentuk sosialisasi produk-produk hukum yang sungguh perlu ditingkatkan sebab dengan berhasilnya upaya preventif dapat mengurangi tingkat pelanggaran hukum, tentu akan lebih maslahat dan tidak menimbulkan kerugian yang lebih besar dibandingkan dengan upaya represif setelah terjadinya pelanggaran. Dengan demikian, penegak hukum dapat melaksanakan fungsinya sebagai pengayom, sesuai dengan tujuan hukum, yaitu keadilan dan ketertiban, karena fungsi hukum itu sendiri selain sebagai pencipta keteraturan (order), juga harus dapat memberikan perlindungan bagi rakyat untuk memperoleh keadilan bukan untuk menyengsarakan. ${ }^{21}$

Dinamika kehidupan masyarakat sudah semestinya dilengkapi dengan pembaharuan hukum nasional yang baik, hukum yang baik adalah hukum yang selalu mengikuti perkembangan masyarakat. Perubahan dan perkembangan masyarakat selalu bergerak dinamis ${ }^{22}$. Dinamika bekerjanya hukum menurut Chamblis dan Seidman dipengaruhi oleh variable-variabel di dalam domain pemerintah, pemegang peran dan institusi penegak hukum serta variable timbal balik serta tuntutan masyarakat luar, berikut diketengahkan bagan bekerjanya hukum.

$20 \quad$ Ibid, hlm. 111

21 Ibid, hlm. 135. Dalam hlm. ini yang penulis maksud adalah dengan melindungi pengendara atau pejalan kaki dari kejahatan tindak pidana lalu lintas salah satunya adalah kealpaan yang mempunyai dampak yang sangat luas karena membahayakan jiwa atau hidup masyarakat pengguna jalan lainnya.

22 Muhammad Fauzan, Djumadi, dan Riris Ardhanariswari "Perumusan Ketentuan Pidana Dalam Pembentukan Peraturan Daerah (Studi di Kabupaten Purbalingga)", Jurnal Dinamika Hukum Vol. 8 No. 2 Mei 2008, Purwokerto: FH Unsoed, hlm. 160. 




Bagan 1. Bekerjanya Hukum

Dari ragaan mengenai bekerjanya hukum di atas dapat penulis kemukakan bahwa meskipun penegakan hukum pidana lalu lintas berupa sanksi pidana (penal) menjadi tuntutan aturan normatif atau undang-undang tertulis yang dianggap absolute dan benar terhadap pelaku kejahatan yang dilandasi oleh asas sembrono (recklessness principle), tetapi mengingat tujuan negara menekankan kepada pemerintah melalui alat penegak hukumnya untuk melindungi segenap Bangsa Indonesia, maka berarti politik hukum pidana lalu lintas atau criminal law policy yang akan dijalankan oleh pemerintah hendaknya selalu dilandasi oleh asas keseimbangan berdasarkan keadilan sosial, yaitu melindungi setiap orang, baik menjadi korban ataupun pelaku tindak kejahatan atas dasar asas recklessness hingga tuntas saat atau pasca kejadian, sebab dalam hal asas recklessness terdapat nuansa ambigu yang menghubungkan jurang pemisah antara asas dolus dan asas culpa. Sehingga perlu dicermati secara detail kesalahan atau mens rea dari pihak-pihak yang terlibat di dalam kecelakaan lalu lintas. Dengan begitu dapat diterapkan pemidanaan kepada pelaku kejahatan dan memulihkan penderitan jasmaniah dan rohaniah dari korban kejahatan ${ }^{23}$ sebagai akibat

23 Sri Wahyuni, "Kebijakan Hukum Pidana dalam Memberikan Perlindungan Hukum Terhadap Korban Tindak Pidana Kejahatan dalam Sistem Peradilan Pidana di Indonesia", Jurnal Pembaharuan Hukum, Vol. 4 No. 2, Edisi Oktober 2008, Semarang: Program Magister Ilmu Hukum, Pascasarjana Universitas Diponegoro Semarang, hlm. 81.
Jadi, politik sebab penderitaan seseorang yang menjadi korban tindak pidana atau (perlakuan sembrono/recklessness. Pen) tidak berhenti pada saat selesainya kejahatan dilakukan ${ }^{24}$ serta melindungi keselamatan pelaku tindak kejahatan atas dasar asas recklessness tersebut dari kesewenang-wenangan penguasa (polisi, jaksa, hakim) dan ataupun main hakim sendiri dari masyarakat, yaitu melalui konsep restorative justice.

Politik hukum pidana atau kebijakan hukum pidana (penal policy/criminal law policy/ strafrechts-politiek) dalam konteks negara hukum Indonesia harus didasarkan kepada asas komunal Pancasila, karena penal policy merupakan bagian dari kebijakan perlindungan social (social defence policy). Oleh karena itu, asas Recklessnes sebagai cermin budaya dapat menjadi input pembuatan hukum, yang kemudian output hukum berupa instrumen perekayasa sosial yang dilandasi nilai Pancasila yaitu produk hukum yang meletakkan tujuan pidana bukan untuk memberikan balas dendam kepada pelaku tindak pidana akan tetapi lebih menekankan konsep permaafan atau mediasi penal atau perdamaian sebagai bentuk restorative justice untuk mencapai tujuan negara.

Melalui mediasi penal diharapkan usaha mewujudkan pembaharuan sistem hukum pidana lalu lintas secara menyeluruh dan terintegral meliputi substansi hukum atau perundang-undangan pidana lalu lintas, struktur hukum atau organ penegak hukum dan budaya perilaku masyarakat dalam berlalu lintas tidak menjadi obscure liable atau samar karena penafsiran asas recklessness yang diidentikkan dengan suatu perbuatan pidana atas dasar asas kelalaian (culpa).

Tujuan politik hukum pidana lalu lintas untuk menciptakan tata tertib melalui pembuatan hukum (law making), penerapan dan penegakan (Rule Sactioning Institutions) di dalam masayarakat (Role Occupant) dapat memberikan keadil-

24 Maria Goretti Etik Prawahyanti, “Perlindungan Hukum Bagi Perempuan dalam Sistem Peradilan Pidana Terpadu Penanganan Kasus Kekerasan Terhadap Perempuan di Indonesia”, Jurnal Pembaharuan Hukum, Vol. 3 No. 2, Edisi Oktober 2007, Semarang : Program Magister Ilmu Hukum, Pascasarjana Universitas Diponegoro Semarang, hlm. 27. 
an, kemanfaatan, kemakmuran dan kesejahteraan dan kepastian hukum bagi setiap manusia. Khususnya korban kejahatan atau kecelakaan yang diakibatkan oleh segala bentuk perilaku sembrono (recklessness) pengguna jalan raya yang cenderung telah beringsut atau bergeser paradigma alon-alon asal kelakon (atau keselamatan lebih utama ketimbang kecepatan) menuju paradigma mengutamakan kecepatan ketimbang keselamatan yang sepertinya sudah menjadi hal lumrah di era perubahan teknologi transportasi global, fenomena tersebut dapat diperhatikan dengan jelas di sekitar lingkungan kehidupan moderen sekarang ini.

\section{Penutup}

Simpulan

Perilaku kesembronoan atau recklessness adalah salah satu faktor penyebab terjadinya kecelakaan lalu lintas. Namun selama ini penerapan Asas recklessness ke dalam pembaharuan hukum pidana lalu lintas belum secara implisit diformulasikan secara khusus. Belum diterapkannya Asas recklessness berakibat menimbulkan masalah yang cenderung mengganggu bekerjanya sistem hukum pidana lalu lintas yang ada khususnya Pasal 310 UU Lalu lintas yang hanya mengacu kepada asas kelalaian yang cenderung tidak dapat menyelesaikan kasus-kasus yang kesalahannya di dasarkan atas perilaku sembrono (Recklessness).

Recklessness sebagai cermin budaya masyarakat dapat menjadi sumber masukan atau input dalam pembaharuan hukum pidana nasional khususnya di bidang lalu lintas, yaitu dengan mengedepankan pembangunan budaya hukum tertib lalu lintas yang berlandaskan Pancasila untuk mencapai tujuan negara.

\section{Daftar Pustaka}

Abdullah, Saiful. "Kebijakan Hukum Pidana (Penal) dan Non Hukum Pidana (Non Penal) dalam Menanggulangi Aliran Sesat". Jurnal Pembaharuan Hukum, Vol. 4 No. 1 Edisi April 2009. Semarang: Program Magister Ilmu Hukum, Pascasarjana Universitas Diponegoro Semarang;
Arief, Barda Nawawi. 2010. Bunga Rampai Kebijakan Hukum Pidana (Perkembangan Penyusunan Konsep KUHP Baru). Jakarta: Kencana;

Black's Law Dictionary Legal Dictionary 2nd Ed;

Budiyono. "Peran Bank Indonesia dalam Penanggulangan Tindak Pidana Perbankan". Jurnal Dinamika Hukum, Vol. 11 Edisi Khusus Februari 2011. Purwokerto: FH Unsoed;

Dwisvimiar, Inge. "Keadilan dalam Perspektif IImu Hukum". Jurnal Dinamika Hukum Vol. 11 No. 3, Edisi September 2011. Purwokerto: FH Unsoed;

Fauzan, Muhammad. Djumadi dan Riris Ardhanariswari. "Perumusan Ketentuan Pidana Dalam Pembentukan Peraturan Daerah (Studi di Kabupaten Purbalingga)". Jurnal Dinamika Hukum Vol. 8 No. 2 Mei 2008. Purwokerto: FH Unsoed;

Kim, So Woong. "Kebijakan Hukum Pidana dalam Upaya Penegakan Hukum Lingkungan Hidup". Jurnal Dinamika Hukum, Vol. 13 No. 3, September 2013. Purwokerto: FH Unsoed;

Moeljatno. 2008. Asas-Asas Hukum Pidana. Jakarta: PT. Rineka Cipta;

Prawahyanti, Maria Goretti Etik. "Perlindungan Hukum Bagi Perempuan dalam Sistem Peradilan Pidana Terpadu Penanganan Kasus Kekerasan Terhadap Perempuan di Indonesia”. Jurnal Pembaharuan Hukum, Vol. 3 No. 2, Edisi Oktober 2007. Semarang: Program Magister Ilmu Hukum, Pascasarjana Universitas Diponegoro Semarang;

Raharjo, Agus. "Problematika Asas Retroaktif dalam Hukum Pidana Indonesia". Jurnal Dinamika Hukum, Vol. 8, No. 1, Edisi Januari 2008. Purwokerto: FH Unsoed;

Samekto, FX. Adji. "Relasi Hukum dengan Kekuasaan: Melihat Hukum dalam Perspektif Realitas". Jurnal Dinamika Hukum, Vol. 13 No. 1, Edisi Januari 2013, Purwokerto: FH Unsoed;

Sulistyanta. "Implikasi Tindak Pidana Di Luar KUHP dalam Hukum Acara Pidana (Studi Kasus Taraf Sinkronisasi)". Jurnal Dinamika Hukum, Vol. 13 No. 2, Mei 2013. Purwokerto: FH Unsoed;

Utami, Tuti Budhi. "Kebijakan Hukum Pidana dalam Menanggulangi Tindak Pidana Illegal Logging". Jurnal Pembaharuan Hukum, Vol. 3 No. 2, Edisi Oktober 2007. Semarang: Program Magister IImu Hukum, 
Pascasarjana Universitas Diponegoro Semarang;

Wahyuni, Sri. "Kebijakan Hukum Pidana dalam Memberikan Perlindungan Hukum Terhadap Korban Tindak Pidana Kejahatan dalam Sistem Peradilan Pidana di Indonesia”. Jurnal Pembaharuan Hukum, Vol. 4 No. 2, Edisi Oktober 2008. Semarang: Program Magister Ilmu Hukum, Pascasarjana Universitas Diponegoro Semarang;

Yuherawan, Deni SB. "Kritik Ideologis Terhadap Dasar Kefilsafatan Asas Legalitas Dalam Hukum Pidana". Jurnal Dinamika Hukum Vol. 12 No. 2, Edisi Mei 2012, Purwokerto: FH Unsoed. 